Portland State University

PDXScholar

Communication Faculty Publications and

Presentations

Communication

Winter 2011

\title{
Community Newspapers Play Significant Role in Election
}

Lee Shaker

Portland State University, Ishaker@pdx.edu

Follow this and additional works at: https://pdxscholar.library.pdx.edu/comm_fac

Part of the Communication Technology and New Media Commons, Journalism Studies Commons, and the Mass Communication Commons

Let us know how access to this document benefits you.

\section{Citation Details}

Shaker, L. (2011). Community Newspapers Play Significant Role in Election. Newspaper Research Journal, 32(1), 6-18.

This Article is brought to you for free and open access. It has been accepted for inclusion in Communication Faculty Publications and Presentations by an authorized administrator of PDXScholar. Please contact us if we can make this document more accessible: pdxscholar@pdx.edu. 


\title{
Community Newspapers Play Significant Role in Election
}

\author{
by Lee Shaker
}

This article compares coverage of the 2007 Philadelphia mayoral campaign in the city's major daily and community newspapers. The findings show that community newspapers serve as a complement to the dailies but also prove to be sources of campaign information in their own right.

$\mathrm{I}_{\mathrm{n}}$

the past few years, the perilous economic position of American newspapers has been widely chronicled in the popular press and by scholars. ${ }^{1}$ Often lost in this discussion is the plight of newspapers other than dominant major dailies_-neighborhood and small-town newspapers, the alternative press, the ethnic press and so on. Those community newspapers are facing many of the same challenges as major dailies, such as a difficult advertising environment and increased competition from online-only media delivered to various digital devices. At the same time, community newspapers have different business models than many major metro papers and, as smaller and more nimble operations, the potential to more quickly adapt to new circumstances. Although their future is in no way guaranteed, it is likely that many community newspapers will find ways to survive. And, as major dailies wither across America, other sources of local news - including community newspapers-will become more important in both small towns and large cities. Already, there are signs that the narrow, local focus of community newspapers has protected them from the circulation losses that plague their larger counterparts. ${ }^{2}$

To some extent, the local media environment in every city is unique. But, many large cities are facing similar declines in the viability of their major daily newspapers. Philadelphia is one such city, as the Inquirer and Daily News have

Shaker is a senior research specialist in the Department of Politics at Princeton University. 
teetered in or on the edge of bankruptcy for years since parting ways with Knight Ridder in 2006. Philadelphia also has a robust population of community newspapers-two city-wide alternative weeklies cover local affairs as well as local entertainment. Several papers target segments of the population by ethnicity; a dozen neighborhood papers are published at least once a week. In addition, the circulation of the free Metro is 120,000 every weekday, and the city even has a newspaper dedicated to covering just the public schools- the Notebook, which publishes 57,000 copies every other month. Given the decline of the city's major daily newspapers and the preponderance of community newspapers, Philadelphia offers an ideal venue to examine the role that both kinds of newspapers play in local politics.

This article analyzes the content of Philadelphia's major dailies and a sample of its community newspapers in the context of the 2007 Philadelphia mayoral campaign. Prior studies of the effects of new technologies upon local media environments have primarily focused on the contents of major daily newspapers. ${ }^{3}$ Meanwhile, scholarly work that explores the weekly urban press"community newspapers" by another name-illustrates the role that those papers play in knitting communities together. ${ }^{4}$ By assessing a broad sample of Philadelphia's many newspapers, this article melds those disparate bodies of literature together. Two straightforward questions drive the analysis: What kinds of mayoral campaign information did local newspapers provide? How did coverage of the mayoral campaign in community newspapers differ from the coverage in major dailies? The findings provide a glimpse into the local political content choices recently available in print to Philadelphia citizens.

\section{Literature Review}

Research into the role that political information plays in the functioning of democracy is an enduring thread of communication scholarship. ${ }^{5}$ Such inquiries begin with the notion that information is necessary grist for effective democracy. ${ }^{6}$ Although there are conflicting perspectives of precisely how much information citizens need or require, there is

\section{...clear evidence that the amount of information one possesses shapes attitudes and behaviors, including such things as participation, voting behavior, tolerance and information processing strategies. ${ }^{7}$}

This article is concerned with three kinds of political information. First, mobilizing information is simple factual data about election times, registration deadlines and campaign events that are vital in alerting and organizing the electorate. ${ }^{8}$ Substantive political information has two dimensions considered separately in this study-issue coverage of the actions taken by governmental bodies or the positions and characteristics of representatives and candidates and coverage of the strategic aspects of politics, also known as the "horse-race," 
such as the popularity of various ideas, officials and candidates. ${ }^{9}$ Citizens can learn about local political affairs through direct experience and interpersonal interactions, but studies of local political activity confirm that mass media are critical components of the localpolitics landscape. ${ }^{10}$

Despite widespread interest in understanding the role of mass-mediated political information in the context of national politics, research with local political information (LPI) at its crux is sparse. The smattering of such research suggests that both the mobilizing and substantive political information provided by mass media are necessary components of healthy community democracies. ${ }^{11}$ Studies of recent changes in the information environment- the rise of broadcast media, chain ownership of newspapers and cable TV—have typically found that those technological advances were correlated with a reduction in the accessibility of LPI. ${ }^{12}$

Examinations of the LPI content of local news are typically limited to electoral periods and have two primary issues of concern-how much LPI exists and what frame, "strategy" or "issue" is most often employed. In the past 25 years, four significant projects have analyzed coverage of mayoral elections in local newspapers. ${ }^{13}$ Notably, one of those projects documented the local media environment in Philadelphia during the 1990s and provided a basis for comparison for the results of this study. ${ }^{14}$ Similar studies of local TV news conclude that it is composed primarily of stories about national topics or local crime and includes very little coverage of local political topics. ${ }^{15}$

The consensus of the literature is that, even if somewhat wanting, the local political content provided by newspapers is unmatched by any other media. That said, there are several clear limitations of the literature. First, prior works capture only the broadest strokes of the relevant coverage, sacrificing details such as the prevalence of mobilizing information or of the cross-promotion of other related media. Second, the differences between primary and general election cycles have not been thoroughly documented. And, most relevant to the current project, those prior content analyses focused narrowly upon the major daily newspapers.

Starting with Janowitz's 1952 work examining the weekly urban press in Chicago, community newspapers are the object of a useful vein of scholarly literature. ${ }^{16}$ That line of research depicts the integrative function played by community newspapers. Community newspapers are more likely to be read by long-term residents who own their homes, and readership predicted awareness of local issues. ${ }^{17}$ The content of those newspapers was specific and contributed to community awareness; ethnographic research showed that such a role had been embraced by the newspapers' staffs. $^{18}$ Taken together, the literature on community newspapers and neighborhood integration suggests that the LPI found in community newspapers may differ qualitatively from that found in major dailies. To address that possibility, this article evaluates and compares six newspapers in Philadelphia. 


\section{Research Questions}

Mayoral elections often are high-profile, high-stakes events that demand attention. The 2007 Philadelphia campaign was for an open seat, fell in an off year for national elections and took place during a period of upheaval in the local media environment. The race paired a competitive Democratic primary in May-won by former city councilman Michael Nutter, who surged from behind to defeat two U.S. representatives, Chaka Fattah and Bob Brady-with a nearly uncontested general election in which there was only a nominal challenge to Nutter, the eventual victor, from Republican Al Taubenberger. As a case study, Philadelphia's 2007 campaign provided the opportunity to zero in on local election coverage in two very different elections, the competitive primary and the non-competitive general, that reflect the political happenings of other cities in the United States.

As major urban news institutions decline, concern that communities will be without viable suppliers of LPI is increasing. ${ }^{19}$ So, the first task of the analysis is to establish a baseline understanding of the amount of LPI available to citizens in print. Accordingly, the first research question is very simple:

\section{RQ1:}

How much coverage did the 2007 Philadelphia mayoral campaign elicit from the local press?

The next research questions examine the characteristics of the local political content offered by the six newspapers to test the possibility that community newspapers provide different kinds of LPI than do major dailies. Hewing to the guidelines established by previous content analyses of political information, three related research questions guide that comparison.

\section{RQ2a:}

How does the mix of issue and strategy LPI compare between major daily and community newspapers?

\section{$R Q 2 b$ :}

How much mobilizing information is provided by major daily and community newspapers?

\section{$R Q 2 c:$}

How frequently do major daily and community newspapers promote other sources of LPI?

The last research question compares the LPI available from the six newspapers during the primary and general elections. Cross-election comparisons have rarely been made, and no such work including community newspapers 
could be found by this author. Prior scholarship suggests that less competitive campaigns are accompanied by more issue-oriented coverage, but that conclusion is drawn from the basis of the strategy-oriented coverage that dominates major dailies during competitive races ${ }^{20}$ Community newspapers, which may provide a different content mixture in general, may complicate that conclusion, prompting the third research question:

RQ3:

How does campaign coverage differ, across primary and general elections, in major daily and community newspapers?

\section{Method}

Coverage of the 2007 Philadelphia mayoral campaign was collected for six weeks in advance of both the primary and general elections from six Philadelphia newspapers: The Philadelphia Inquirer, The Daily News, The Tribune, Metro, Northeast Times and Philly Weekly. The first two papers are the major dailies in Philadelphia; the other four are, respectively, the ethnic paper for the black community, a free weekday paper, a neighborhood weekly and an entertainment-focused alternative weekly. Coverage in the major dailies is compared to coverage in the other four newspapers both individually and as two groups, major dailies and community newspapers.

Coding for the content analysis was carried out by the author and two undergraduate students. Among the categories of analysis, assessing the substantive LPI required the most attention. Strategy content was defined as information that "describes the campaign strategies and the competition between the candidates" and five sub-categories, with specific examples, of qualifying information were provided-polling data, campaign funding, advertising strategies, electoral 
strategies and endorsements. Coding for issue content included nine relevant issues that were identified for coders, but coders also had leeway to identify other pertinent issues that appeared. Coding of the remaining variables-the presence of mobilizing information, the presence of cross-promotion of other media, such as a website-was dictated by guidelines and examples not described here but straightforward in nature.

A total of 630 newspaper articles were coded for this study. Intercoder reliability was established by comparing the coding of a randomly selected sample of 10 percent of the articles across all publications using Krippendorff's alpha as the metric of agreement. According to Krippendorff, the ideal level of agreement is greater than .80 , but levels above .667 are acceptable. ${ }^{21}$ The agreement levels for this content analysis range between .67 and .83 for all variables except the assessment of the presence of mobilizing information. After reviewing the reliability scores, the coders conferred about the discrepancies and reached a consensus before proceeding to complete the remaining coding.

\section{Findings}

RQ1: This study finds that the 2007 Philadelphia mayoral campaign resulted in substantial coverage from the city's press. [See Table 1]

Of the 630 relevant pieces, the Inquirer published the most articles (189) and the Metro (141) and Daily News (131) printed comparable numbers of pieces. In the sample, the major dailies (the Inquirer and Daily News) published 320 articles and the community papers together published 310 pieces. On an article-per-issue basis, the range among the papers was from 1.75 to 3.17 articles per edition, with the Tribune and the Northeast Times publishing pieces most frequently. The bulk of articles (454) were printed during the primary period and many fewer (176) were published in the general election period. The decline in coverage was similar for the Inquirer, Daily News and Tribune, as each printed about onethird as many pieces about the general election as about the primary election.

\begin{tabular}{lcclllll}
$\begin{array}{l}\text { Table 1 } \\
\text { Article Distribution }\end{array}$ & Primary & General & $\begin{array}{l}\text { Articles } \\
\text { Per Issue }\end{array}$ & News & Op-Ed & Letters & Other \\
Newspaper & & & & & & \\
& 139 & 50 & 2.25 & 137 & 37 & 11 & 4 \\
Inquirer & 95 & 36 & 1.82 & 85 & 28 & 10 & 8 \\
$\begin{array}{l}\text { Daily News } \\
\text { Tribune }\end{array}$ & 82 & 28 & 3.06 & 88 & 19 & 0 & 3 \\
$\begin{array}{l}\text { Metro } \\
\text { Philly Weekly }\end{array}$ & 99 & 42 & 2.35 & 128 & 4 & 5 & 4 \\
Northeast Times & 18 & 3 & 1.75 & 10 & 8 & 3 & 0 \\
Total & 21 & 17 & 3.17 & 29 & 3 & 6 & 0 \\
\hline
\end{tabular}


Proportionately, the trend was not as strong for the Metro (42 percent as many pieces during the general election) and Northeast Times (81 percent), but coverage virtually disappeared from the pages of Philly Weekly (17 percent). Articles in the general period were more than 10 percent shorter as well. [See Table 3] Across all publications, most relevant articles were hard news coverage (76 percent). That distinction was particularly pronounced in the Metro (91 percent); about 30 percent of the coverage in the other publications was in the form of op-eds or letters to the editor.

RQ2a-c: The mayoral campaign coverage included in this sample contains an array of pertinent LPI.

More than a third of the articles (37 percent) included mobilizing information. Just 14 percent contained teasers that offered additional information elsewhere. About half of all stories included substantial information about campaign strategy (52 percent) or issues (49 percent). Analysis shows that the LPI provided by the six newspapers varies in several notable ways. [See Table 2]

First, articles in the major dailies were significantly more likely to contain strategy-focused LPI than those in the community newspapers. [See Table 3] The major dailies' articles were also significantly longer, more likely to contain mobilizing information and more likely to refer to websites or other related sources of information. Articles in the community papers were more likely to contain issue-focused information, but the difference was not significant. That said, articles in community papers did contain significantly more issue-focused information on average than did the articles in the major dailies.

Looking at "issue" and "strategy" content at a more granular level, half of

\section{Table 2 \\ LPI Content of Newspaper Articles}

\begin{tabular}{|c|c|c|c|c|c|c|c|c|}
\hline Newspaper & $N$ & Words & $\begin{array}{l}M I \\
\%\end{array}$ & $\begin{array}{l}\text { Teaser } \\
\%\end{array}$ & $\begin{array}{l}\text { Strategy } \\
\%\end{array}$ & $\begin{array}{l}\text { Strategy } \\
0-5\end{array}$ & $\begin{array}{l}\text { Issue } \\
\%\end{array}$ & $\begin{array}{l}\text { Issue } \\
0-5\end{array}$ \\
\hline Inquirer & 189 & 764 & $50 \%$ & $24 \%$ & $59 \%$ & 1.04 & $54 \%$ & 1.14 \\
\hline Daily News & 131 & 529 & $28 \%$ & $11 \%$ & $55 \%$ & 1.00 & $45 \%$ & 0.95 \\
\hline Tribune & 110 & 741 & $26 \%$ & $2 \%$ & $50 \%$ & 0.76 & $49 \%$ & 1.32 \\
\hline Metro & 141 & 262 & $34 \%$ & $13 \%$ & $43 \%$ & 0.71 & $49 \%$ & 1.01 \\
\hline Philly Weekly & 21 & 767 & $33 \%$ & $10 \%$ & $45 \%$ & 0.65 & $60 \%$ & 1.75 \\
\hline Northeast Times & 38 & 693 & $47 \%$ & $16 \%$ & $61 \%$ & 1.24 & $87 \%$ & 3.24 \\
\hline $\begin{array}{l}\text { Major Dailies } \\
\text { Community }\end{array}$ & 320 & $668^{* *}$ & $41 \%^{*}$ & $36 \%$ & $57 \% *$ & $1.02^{* *}$ & $49 \%$ & $1.06^{* *}$ \\
\hline Papers & 310 & $519^{* *}$ & $33 \%{ }^{*}$ & $17 \%$ & $48 \%{ }^{*}$ & $0.79^{* *}$ & $54 \%$ & $1.46^{* *}$ \\
\hline All Papers & 630 & 595 & $37 \%$ & $14 \%$ & $52 \%$ & 0.91 & $49 \%$ & 1.25 \\
\hline
\end{tabular}


the publications had a higher proportion of articles with strategic information than issue-related information: the Inquirer, Daily News and Tribune. The opposite was true of Philly Weekly, the Northeast Times and the Metro. The contents of the Inquirer, in particular, stand out as rich: mobilizing information was included in 50 percent of its articles and the paper included references to other information resources more frequently (24 percent of articles) than any other publication.

RQ3: Comparing articles published in advance of the primary and general elections adds some nuance to this examination of publications.

At a basic level, the mix of issue- and strategy-focused information across all papers clearly differed between election periods. [See Table 3] Before the primary election, 63 percent of articles included strategy information and 46 percent contained issue information. Before the general election, 26 percent of articles included strategy information and 66 percent contained issue information. Both differences were significant, although the disparity in volume between the periods noted above should be kept in mind.

Turning to comparisons between major dailies and community papers within each period [See Table4] helps further isolate the roles that the newspapers play in the local media environment. Differences between the paper types were much sharper in the primary period than during the general election's timeframe. During the primary period, articles in major dailies were significantly more likely to contain mobilizing information, teasers and strategic information. Articles in community newspapers, however, were significantly more likely to 


\begin{tabular}{|c|c|c|c|c|c|c|c|c|}
\hline Primary & $N$ & Words & $\begin{array}{l}M I \\
\%\end{array}$ & $\begin{array}{l}\text { Teaser } \\
\%\end{array}$ & $\begin{array}{l}\text { Strategy } \\
\%\end{array}$ & $\begin{array}{l}\text { Strategy } \\
0-5\end{array}$ & $\begin{array}{l}\text { Issue } \\
\%\end{array}$ & $\begin{array}{l}\text { Issue } \\
0-5\end{array}$ \\
\hline $\begin{array}{l}\text { Major Dailies } \\
\text { Community }\end{array}$ & 234 & $689^{* * *}$ & $44 \% \%^{* *}$ & $31 \%{ }^{*}$ & $69 \%{ }^{*}$ & $0.69^{* *}$ & $41 \%^{*}$ & $0.85^{* *}$ \\
\hline Papers & 220 & $537^{* *}$ & $31 \%$ & $18 \%{ }^{*}$ & $57 \%{ }^{*}$ & $0.57^{* *}$ & $51 \%{ }^{*}$ & $1.39^{* *}$ \\
\hline General & $N$ & Words & $\begin{array}{l}M I \\
\%\end{array}$ & $\begin{array}{l}\text { Teaser } \\
\%\end{array}$ & $\begin{array}{l}\text { Strategy } \\
\%\end{array}$ & $\begin{array}{l}\text { Strategy } \\
0-5\end{array}$ & $\begin{array}{l}\text { Issue } \\
\%\end{array}$ & $\begin{array}{l}\text { Issue } \\
0-5\end{array}$ \\
\hline $\begin{array}{l}\text { Major Dailies } \\
\text { Community }\end{array}$ & 90 & $609^{* *}$ & $31 \%$ & $50 \%$ & $26 \%$ & 0.42 & $71 \%$ & 1.64 \\
\hline Papers & 87 & $474^{* *}$ & $38 \%$ & $12 \%{ }^{* *}$ & $26 \%$ & 0.37 & $61 \%$ & 1.63 \\
\hline
\end{tabular}

provide issue information and more of it as well. During the general election, the only significant difference in those categories was that more of the articles in major dailies included references to other sources of information than the articles published by community papers.

\section{Discussion}

Three particular points emerge from the findings of this study. First, although Philadelphia's primary daily paper, the Inquirer, provided the most coverage, a sizeable amount of nuanced reporting was available from community newspapers. Second, the type of coverage available from major dailies and community newspapers was qualitatively different. Third, the characteristics of the campaign coverage varied dramatically between the two election periods.

The first research question probed the amount of LPI that was available to citizens. In short, as major dailies struggle to stay afloat, it is important to know what other sources of LPI exist. In this case, the major dailies provided more campaign information than did the community newspapers, but they were clearly not the only viable source of relevant LPI. Certainly, the collapse of the Inquirer or Daily News would be a loss for Philadelphia, but the community newspapers already appear to provide a viable substitute, at least in their coverage of the 2007 Philadelphia mayoral election.

The LPI provided by community papers did differ in some notable ways from that published by the major dailies. The community newspapers published shorter articles with more of an emphasis on issue information. At the same time, their articles offered mobilizing information less frequently and did not 
provide as much strategicinformation. Given the divergent production schedules of the community papers (none is published seven days a week) and the major dailies, those differences likely reflect the complementary nature of the various newspapers. Citizens would do best to read a daily paper, which would alert them to campaign events and provide horse-race updates, and a community paper that provides in-depth issue information. But, to some extent, the community newspapers' coverage-which was especially issue-centric during the primary election-provided the most important information for citizens interested in evaluating candidates. Reading just a community paper would have yielded sufficient issue information to make a knowledgeable electoral choice.

Generally speaking, treatment of the mayoral campaign varied some across the six newspapers, but perhaps not as much as might be expected. Community newspapers did complement the major dailies, but they were vital in their own regard. They each serve and conform to a particular niche-commuters, a neighborhood or a particular demographic. In doing so, they become useful and unique LPI resources. Scholars have previously illustrated community newspaper staffs' dedication to and integration with their neighborhoods. ${ }^{22}$ Perhaps not surprisingly, the findings here show that community papers are a vibrant part of the local media environment and, as the foundation of major dailies erodes, suggest that they warrant further scholarly attention.

Turning to the amount and type of LPI available across the election periods, some prior researchers have struck an optimistic note about the mix of issue and strategy coverage in certain campaign circumstances. ${ }^{23}$ They suggest that in lightly contested elections, issue-focused coverage comes to the fore- a finding that is partially echoed here. There was a pronounced shift on the surface toward issue-centric coverage between the primary and general election periods. But, that change was much more pronounced in coverage in the major dailies than in the community papers: issue coverage only came to the fore in the Inquirer and Daily News once there no longer was a horse race to cover. Meanwhile, it was the center of the community papers' coverage all along.

Additionally, the transition in news focus across time periods was paired with a dramatic reduction in the total amount of relevant coverage between the primary and general elections. To a large extent, the coverage that did exist in the general election period folded the campaign, or its candidates, into existing local political news narratives. Pieces about ongoing debates in the city often assessed Michael Nutter's positions and likely impact on those issues. Those articles-although they were "campaign coverage" in that the candidates were mentioned-are not comparable to issue-focused reporting before the primary because the candidate and the campaign may have been an afterthought. In short, prior scholars' optimism regarding an increased issue-focus in campaign coverage of lightly contested elections understates other significant drawbacks of the reporting in such circumstances. 


\section{Conclusion}

Modern, representative democracy in America has always involved newspapers. Citizens need mediated sources of local political information, governments need channels to disseminate information and communities need a mechanism of oversight of their public officials. Writing about the 1991 Philadelphia mayoral campaign, Kaniss looked extensively at the city's two major daily newspapers which then had a combined circulation of more than 700,000..$^{24}$ At this writing, the combined circulation of the Inquirer and Daily News was about $360,000 .{ }^{25}$ As the slow-motion decline of newspapers proceeds across the United States, it is reasonable to wonder what institutions will connect citizens and politicians in the future. Certainly, major daily newspapers have long filled that role, but they are not the only news organizations to do so. This article outlines the contributions of smaller, community-oriented publications and suggests that they may partially fill the voids left by major dailies.

Although not the dominant cultural institutions that major dailies were throughout the 20th century, community newspapers have been and remain an important resource. And, as major dailies shrink or collapse under the strain of high cost structures and low advertising and circulation revenue, there is opportunity for community news organizations to grow in stature. Like the major dailies, community papers also face significant financial challenges, but they tend to have lower overhead and traditions of thrift. They may not all survive the current turmoil in the newspaper industry, but the ones that do could be increasingly important to the communities that they serve. Still, in order for urban community newspapers to survive and thrive, they must carefully consider their audiences and roles. The information they offer, typically an aggregation of geographically-specific information that is not available elsewhere and that is pertinent to a niche audience, must be compelling enough to drive a community's interest. As recent history shows, an available supply of local news is not sufficient to guarantee its consumption. The task that falls to the writers, editors and publishers of community newspapers is to induce citizens to read at least one local paper.

\section{Notes}

1. Eric Alterman, "Out of Print," The New Yorker, March 31 2008, <http:/ / www.newyorker. com/reporting / 2008/03/31/080331fa_fact_alterman?currentPage=all > (April 12, 2010); Michael Sokolove, “What's a Big City Without a Newspaper?," The New York Times, Aug. 6, 2009, <http:/ / www.nytimes.com/2009/08/09/magazine/09Newspaper-t.html?_r=1\&pagewanted=all> (April 12, 2010); Philip Meyer, The Vanishing Newspaper: Saving Journalism in the Information Age (Columbia, MO: University of Missouri Press, 2004); Robert McChesney and John Nichols, The Death and Life of American Journalism: The Media Revolution that Will Begin the World Again (New York: Nation Books, 2010); Clay Shirky, "Newspapers and Thinking the Unthinkable," Clay Shirky's Writings About the Internet, March 13, 2009, <http:/ / www.shirky.com/weblog/2009/03/ newspapers-and-thinkingthe-unthinkable/> (August 17, 2009); Paul Starr, "Goodbye to the Age of Newspapers (Hello to a New Era of Corruption)," The New Republic, March 4, 2009, <http:/ / www.tnr.com/ politics/story. html?id=a4e2aafc-cc92-4e79-90d1-db3946a6d119> (Aug. 17, 2009). 
2. Frank Ahrens, "The Accelerating Decline of Newspapers: Small dailies are rare bright spot in latest figures," The Washington Post, Oct. 27 2009, <http: / / www.washingtonpost.com/wp-dyn / content/ article/2009/10/26/AR2009102603272.html> (April 12, 2010).

3. George A. Donohue, Clarice N. Olien and Philip J. Tichenor, "Media access and knowledge gaps" Critical Studies in Mass Communication 4, no. 1 (1987): 87-92.

4. Morris Janowitz, The Community Press in an Urban Setting (New York: The FreePress, 1952); Alex S. Edelstein and Otto N. Larsen, "The Weekly Press' Contribution To a Sense of Urban Community," Journalism Quarterly 37, no. 3 (1960): 489-498; Leo W. Jeffres and Jean Dobos, "Communication and Neighborhood Mobilization" Urban Affairs Review 20, no. 1 (1984): 97-112.

5. W. Lance Bennett and Robert M. Entman, Mediated Politics: Communication in the Future of Democracy (New York: Cambridge University Press, 2001).

6. Stephen C. Craig, J.G. Kane and Jason Gainous, "Issue-Related Learning in a Gubernatorial Campaign: A Panel Study," Political Communication 22, no. 4 (2005): 483-503; William P. Eveland, Andrew F. Hayes, Dhavan V. Shah and Nojin Kwak, "Understanding the Relationship Between Communication and Political Knowledge: A Model Comparison Approach Using Panel Data," Political Communication 22, no. 4 (2005): 423-446; John S. Mill, On Liberty. 1859, <http:/ /www. utilitarianism.com/ol/> (Aug. 22, 2009).

7. Philip E. Converse, "The Nature of Belief Systems in Mass Publics," in Ideology and Discontent, ed. David E. Apter, (New York: Free Press, 1964); James N. Druckman, "Does Political Information Matter?" Political Communication 22, no. 4 (2005): 517; Benjamin I. Page and Robert Y. Shapiro, The Rational Public (Chicago: University of Chicago Press, 1992); Michael Schudson, "Why Conversation is Not the Soul of Democracy," Critical Studies in Mass Communication 14, no. 2 (1997): 297-309; Paul M. Sniderman, Richard A. Brody and Philip E. Tetlock, Reasoning and Choice (New York: Cambridge University Press, 1991).

8. James B. Lemert, Does Mass Communication Change Public Opinion After All? A New Approach to Effects Analysis (Chicago: Nelson Hall, 1981); Lindsey M. Hoffman, "Is Internet Content Different After All? AContent Analysis of Mobilizing Information in Online and Print Newspapers," Journalism and Mass Communication Quarterly 83, no. 1 (spring 2006): 58-76.

9. Joseph N. Cappella and Kathleen H. Jamieson, Spiral of Cynicism: The Press and the Public Good (New York: Oxford University Press, 1997); Shanto Iyengar, Is Anyone Responsible? How Television Frames Political Issues (Chicago: University of Chicago Press, 1991).

10. Sidney Verba and Norman N. Nie, Participation in America: Political Democracy and Social Equality (New York: Harper and Row, 1972).

11.Jack M. McLeod, Dietram A.Scheufele and Patricia Moy, "Community, Communication, and Participation: The Role of Mass Media and Interpersonal Discussion in Local Political Participation," Political Communication 16, no. 3 (1999): 315-336; Dietram A. Scheufele, James Shanahan and SeiHill Kim, "Who Cares About Local Politics? Media Influences on Local Political Involvement, Issue Awareness, and Attitudes Strength," Journalism and Mass Communication Quarterly 79, no.2 (summer 2002): 427-444.

12. David P. Demers and Daniel B. Wackman, "Effect of Chain Ownership on Newspaper Management Goals," Newspaper Research Journal 9, no. 4 (fall 1988): 59-68; George A. Donohue, Clarice N. Olien and Philip J. Tichenor, "Are Rural Areas Left Behind In The Age Of Information? More TV And Radio, Fewer Newspapers" Sociology of Rural Life 9, no. 4 (1987): 1-8; George A. Donohue, Clarice N. Olien and Philip J. Tichenor, "Effect of Use of Metro Dailies on Knowledge Gap in Small Towns," Journalism Quarterly 64, no. $2 / 3$ (summer/fall 1987): 329-336; Stephen Lacy, "Effects of Group Ownership on Daily Newspaper Content," Journal of Media Economics 4, no. 1 (1991), pp. 35-47.

13. Julio Borquez and Donna Wasserman, "Patterns of Press Coverage of Mayoral Campaigns: Comparing Detroit and Los Angeles," The Social Science Journal 43, no. 3 (2006):375-391; Doris Graber, "Media Magic: Fashioning Characters for the 1983 Mayoral Race," in The Making of the Mayor, eds. 
Melvin G. Holli and Paul M. Green, (Grand Rapids, Mich.: Eerdmans, 1984); Timothy F. Grainey, Dennis Pollack and Lori Kusmierek, "How Three Chicago Newspapers Covered the WashingtonEpton Campaign" Journalism Quarterly 61, no. 3 (fall 1984): 354-363; Phyllis Kaniss, The Media and the Mayor's Race (Indianapolis: Indiana University Press, 1995).

14. Kaniss, The Media and the Mayor's Race.

15. Martin Kaplan, Steve Rabinowitz and Jesse F. Derris, "Local TV News Coverage of the 2002 General Election," Lear Center Local News Archive <http:/ / www.localnewsarchive.org/pdf / LocalTV2002.pdf> (Aug. 22, 2009); Martin Kaplan, Ken Goldstein and Matthew Hale, "Local News Coverage of the 2004 campaigns," Lear Center Local News Archive <http: / / www.localnewsarchive. org/pdf/LCLNAFinal2004.pdf> (Aug. 22, 2009); Jolene Kiolbassa, "Is Local TV News Still Local?" Harvard International Journal of Press and Politics 2, no. 1 (1997): 79-95; Paul Klite, Robert A. Bardwell and Jason Salzman, "Local TV News: Getting Away with Murder," Harvard International Journal of Press and Politics 2, no. 1 (1997): 102-112; Daniel Stevens, Dean Alger, Barbara Allen and John L. Sullivan, "Local News Coverage in a Social-Capital Capital: Election 2000 on Minnesota's Local News Stations." Political Communication 23, no. 1 (2006): 61-83.

16. Janowitz, The Community Press in an Urban Setting; Keith Stamm and Robert Weis, "The Newspaper and Community Integration: A Study of Ties to a Local Church Community," Communication Research 13, no.1 (1986): 125-137;Jack M. McLeod, Katie Daily, ZhongshiGuo, William P. Eveland, Jr., Jan Bayer, Seungchan Yang and Hsu Wang, "Community Integration, Local Media Use, and Democratic Processes," Communication Research 23, no. 2 (1996): 179-209.

17. Edelstein and Larsen, "The Weekly Press' Contribution To a Sense of Urban Community;" Jeffres and Dobos, "Communication and Neighborhood Mobilization."

18. Edelstein and Larsen, "The Weekly Press' Contribution To a Sense of Urban Community;"

Elizabeth Blanks Hindman, "Community, Democracy, and Neighborhood News," Journal of Communication 48, no. 1 (1998): 27-39.

19. Meyer, The Vanishing Newspaper; McChesney and Nichols, The Death and Life of American Journalism; Starr, "Goodbye to the Age of Newspapers."

20. Borquez and Wasserman, "Patterns of Press Coverage of Mayoral Campaigns: Comparing Detroit and Los Angeles;" Kaniss, The Media and the Mayor's Race.

21. Klaus Krippendorff, Content Analysis: An Introduction to Its Methodology (Thousand Oaks, CA: Sage, 2004).

22. Hindman, "Community, Democracy, and Neighborhood News."

23. Borquez and Wasserman, "Patterns of Press Coverage of Mayoral Campaigns"; Kaniss, The Media and the Mayor's Race.

24. Kaniss, The Media and the Mayor's Race.

25. Audit Bureau of Circulations, "Newspaper Circulation for the period ending Sept. 30, 2009," <http:/ / abcas3.accessabc.com/ecirc/newsform.asp> (Nov. 13, 2009). 
Copyright of Newspaper Research Journal is the property of Newspaper Research Journal and its content may not be copied or emailed to multiple sites or posted to a listserv without the copyright holder's express written permission. However, users may print, download, or email articles for individual use. 